\title{
The Collapse of the International Tin Agreement
}

\author{
Michael Prest
}

\section{Introduction}

Early on the morning of 24 October 1985 Michael Brown, chief executive of the London Metal Exchange, was sitting in his office chatting to the chairman of the exchange's committee, Ted Jordan. The telephone range. It was Pieter de Koning, the International Tin Council's buffer stock manager and the most powerful person in the world tin market. There was a brief conversation. Brown recalls: 'I turned to Ted and said "de Koning has suspended trading".'

In that instant both realised that chaos threatened. Their immediate concern was the LME and its members. They knew that around half of the LME's 27 ring dealing members ${ }^{1}$ were heavily involved with the buffer stock. They also suspected that de Koning's careful word 'suspend' was code for defaulting on his outstanding positions with those firms. There could only be one reason for the buffer stock withdrawing from the market: incredible as it might seem, a body backed by 22 sovereign states had run out of money. Tin was the least traded of the LME's seven metals, but it was immediately obvious that a big default would damage the reputation of the exchange and perhaps of the City of London as an international centre for commodity trading. After a quick consultation with Jacques Lion, the chairman of the LME board, trading in the tin contract was stopped.

By suspending trading the exchange locked itself and its members into the most serious crisis to afflict commodity trading for half a century, from which neither it nor its members has recovered. Worse from its standpoint, the LME became an increasingly

\footnotetext{
1 LME membership is divided into two main categories: 22 active ring dealing members and 63 non-ring dealing members. There are also 36 individual subscribers and 12 honorary members. Ring dealing members, who numbered 27 when the crisis broke, are firms allowed to deal directly on the floor or 'ring' of the exchange. Non-ring dealing members may deal directly with other exchange members but have to put ring dealing business through ring dealing members. All the ring dealing members are owned by bigger companies.
}

unimportant part of an international dispute which it only dimly understood. The field was quickly dominated by national governments, big banks, and in the background the United Nations Conference on Trade and Development.

For the LME the issues were the sanctity of contract and the preservation of the exchange. But for the other participants it was a matter of real politik, in which the stakes were the future of international commodity agreements, the debt crisis, and relations between developing commodity producing countries and industrial consumers of commodities. What originated as a commercial dispute - the announcement by the ITC that it could not pay its debts - rapidly intensified and expanded into a test case of the ability of commodity agreements to survive in adverse market conditions. The ITC seems to have failed the test.

For what nobody - except perhaps a few ITC officials - could have known that morning was what the technical suspension of the buffer stock's trading would reveal. Least of all did they anticipate a six month crisis, at the end of which the ITC's members ${ }^{2}$ - which included all the then members of the European Community - would refuse to honour fully debts of $£ 900 \mathrm{mn}$. As legal actions against the ITC and member countries, including Britain, now accumulate, we can begin to count the cost of the loss of public faith in commodity agreements. Has the ITC's pleading diplomatic immunity as the reason for not paying its debts undermined well-intentioned efforts to introduce some order into commodity trading and prices, and if so by how much?

\footnotetext{
2 The 22 members of the ITC are divided into two groups. The six producer members are Australia, Indonesia, Malaysia, Nigeria. Thailand, and Zaire. The 16 consumer members are Canada, the European Economic Community (Belgium/Luxembourg, Denmark, France, Germany, Greece, Ireland, Italy, Netherlands, United Kingdom), Finland, India, Japan, Norway, Sweden, and Switzerland. The United States and Bolivia were members until 1982. The EEC participates as an inter-governmental organistion.
} 


\section{The Background}

In fact, relations between the LME as the main free market price-setting mechanism for tin and the ITC and some of its more prominent members, notably Malaysia, had been poor for several years. There had been open animosity in 1982 when continuous heavy buying of tin had by February of that year forced the LME cash price of tin to almost $£ 9,000$ a tonne, a premium or 'backwardation' of $£ 1,000$ over the price for delivery in three months, and a rise of 30 per cent in a year. A backwardation is so called because futures prices normally command a premium over cash prices to allow for interest, storage, insurance and similar costs.

The buying looked suspiciously like an attempt to corner the world tin market. Although it was conducted from Switzerland, there was substantial evidence that it was done with the knowledge of, if not the actual approval and financial support of, the Malaysian government. This crisis came to a head when the LME authorities limited by rule the size of the backwardation. This meant that traders with forward commitments to sell tin did not have to pay to the mysterious holder of tin a monopoly price for the metal they needed to fulfill their contracts. The heat was taken out of the market and within a fortnight the three-months price had fallen by almost $£ 2,000$ a tonne. But the LME was bitterly attacked by senior Malaysian politicians.

In retrospect, moreover, the affair sowed the seeds of the much bigger disaster which was to follow four years later. Publicly it highlighted the tension between an exchange founded a century ago at the height of laissez-faire and still run as a cross between a gentleman's club and a bazaar, and a post-war intergovernmental body founded on the principle of regulating the consequences of supply and demand. Mistrust and misunderstanding was to be expected, yet the two organisations had coexisted for 30 years and had even come to depend on each other.

Privately, behind the closed doors of the ITC, it widened the gap between consumer and producer members and even caused some producers such as Indonesia and Thailand, fearful of Malaysia's power as the world's biggest tin producer, to question Malaysia's motives. At one stage in 1982 there was genuine concern that the International Tin Agreement would not be renewed. All these divisions and problems had two common roots: the changing structure of the world tin market and the place of the ITA in it.

\section{The Tin Market \\ Characteristics of Tin}

Tin is one of the oldest known metals. Its low melting point, common occurrence, and ease of working made the metal simple to produce and turn into instruments. Tools and weapons were made from bronze (an alloy of tin and copper) in the fourth millenium BC. The Roman writer Pliny described in AD79 the alloy of lead and tin which we call solder and which is still a major end use for tin. The biggest major modern use, tinplate, was first mentioned in the 17th century. An important characteristic of tin is that most of its applications need only small quantities of the metal. This, along with geographical fluctuations in sources of supply, meant that tin was traded from very early times. The famous example is the Phoenicians buying tin in Cornwall for sale in the Mediterranean.

A free market in the metal, whether the price was set on a recognised exchange or not, therefore antedated by centuries international attempts to control the price. In the modern world, moreover, reserves of tin are substantial, and it is not a commodity likely to suffer geological exhaustion. According to the United States Bureau of Mines [Roskill 1985] total reserves and resources are more than $38 \mathrm{mn}$ tonnes - enough at current consumption rates to last 150 years.

\section{Concentration of Production}

The contemporary tin market has several key characteristics which make it an almost ideal case study of commodity relations between developing and developed countries, regardless of whether events had brought the issue to a head.

First, unlike other important and widely traded industrial base metals such as copper, production of tin is still quite concentrated in a handful of developing countries. Of world mine production of about 214,000 tonnes in 1983 half came from three countries in South-East Asia - Indonesia, Malaysia and Thailand. Despite its steadily falling market share, Malaysia is still the biggest single producer, with a fifth of mine output. South and Central America accounted for another fifth (Bolivia 12 per cent). China was responsible for more than eight per cent. The only two developed countries which figured significantly were the Soviet Union, whose nine per cent share is not traded on the world market, and Australia which mined five per cent of the total [Roskill 1985].

\section{Concentration of Consumption}

Second, the obverse of concentration of production is concentration of consumption. The consumers of tin concentrates and refined metal exported by the producing countries are mainly industrial nations. Thus the United States (which produces virtually no tin at all), Japan, France, West Germany, Italy and the United Kingdom make up more than half of world 
consumption. If one includes the whole European Economic Community, the proportion rises to twothirds. If one then allows that the centrally planned economies import about 13 per cent of all tin metal traded there is little left for developing countries [Roskill 1985]. This pattern has persisted since before the beginning of the century and has changed only to the extent that producing countries now refine most of their mine concentrates into tin metal before export and that tin mining in three of the biggest producers (Malaysia, Indonesia and Bolivia) is now statecontrolled.

\section{Vulnerability of Tin Producers}

Third, tin producers are very vulnerable to the fluctuating economic, and particularly industrial, fortunes of their developed customers. Demand for tin obviously depends upon the health of the consuming economy. But since the oil price increases of $1973 / 74$ it has also become more dependent on the changing structure of developed economies - not just their aggregate output - and on technological and market changes within the industrial sector itself. For example, recent expansion in developed economies has been generated more by services than by industry. Demand for raw materials is therefore growing more slowly than are OECD economies as a whole - as the prevailing lowest real commodity prices this century indicate.

Technological and marketing changes have also sever ely affected demand for tin. But rival materials to tinplate - aluminium and plastics (there is even a prototype plastic Coca Cola can!) - have eroded the market share. Improved technology has enabled tinplate to be made with less tin. Since 1973 the percentage of tin used in tinplate has fallen from 37 per cent to barely 30 per cent, not much more than solder, the second main end use. Two other factors in tin's decline have been its high price relative to competitors and the huge American strategic stockpile (see below).

\section{The Fall in Tin Consumption}

The net effect of all these factors has been a steady fall in tin consumption for more than a decade. From 1945 to its peak in 1974 demand for tin advanced with few setbacks from 97,300 tonnes a year to more than 200,000 tonnes. In 19 of those years demand exceeded supply, especially during the long economic boom of the 1960s. But since 1974 the picture has been very different. Not only has consumption fallen to an estimated 165,000 tonnes in 1985, but the surplus years outnumbered the deficit years. It was against this unfavourable background that the ITC tried to maintain a tin price and the International $T$ in Agreement.

\section{The International Tin Agreement}

\section{Early Tin Agreements}

As the abandoned mineworkings which dominate the landscape of west Cornwall show, the tin market has been prone to instability for a very long time. After several short-lived efforts in the late 1920s and in the 1930s to regulate the price, Malaya, Nigeria, the Dutch East Indies and Bolivia signed in 1931 the first international tin agreement. A subsequent tin agreement lasted until December 1941 and included for the first time the two biggest tin consumers, the United States and Britain.

American involvement in the tin agreement resembles the ambiguity of that country's contemporary attitude towards commodity pacts. The original motive, which owed much to the spirit of the New Deal era, was to encourage an orderly recovery from the slump. But the outbreak of the Second World War concentrated American minds on the strategic importance of tin. In 1940 the United States decided to accumulate a tin stockpile of 75,000 tonnes, to be run by the General Services Administration (GSA). Production soared and just before Japan overran the mines of South-East Asia it reached a record level of 223,000 tonnes a year. Japan's entry into the war and the loss of tin supplies from Asia seemed to justify the American decision to build up a tin stockpile. But it was to prove part of the ITA's undoing.

That, however, was still a long way off. In the years just after the war the Asian mines were quickly rehabilitated and by 1948 production was already exceeding consumption. In 1950 the producers agreed at a UN conference on tin that production cuts were necessary. The United States opposed cuts, however, because it was still buying tin and feared a shortage. In the event, the Korean War stimulated a new boom.

\section{The First International Tin Agreement and its Successors}

A second UN conference, in 1973, was more fruitful. The Korean war had ended and the United States, having accumulated a tin mountain of 40,000 tonnes more than the original target, was in a more cooperative mood. The outcome of the conference was the First International Tin Agreement, which came into force on 1 July 1956. From the start the ITA looked strong. It included all the major western tin producers and consumers, brought together in the more optimistic and liberal atmosphere which then prevailed. It incorporated a target price range to be defended by both a buffer stock and production or export quotas, and also boasted the enlightened feature of giving the producer and consumer groups, into which it was divided, equal votes. 
Producers and consumers subscribed funds to the agreement according to their percentage share of output or use. The first use for these funds was the purchase of 23,700 tonnes of tin to start the buffer stock. A permanent secretariat was formed in London to administer the agreement.

In 1972, the council and its employees were granted (or so it was assumed) diplomatic immunity by the British government's International Tin Council (Immunities and Privileges) Order. Successive five-year agreements were negotiated smoothly enough, and after the formation of UNCTAD in 1964 were conducted under its auspices and with its advice. Indeed, the duration and apparent solidity of the tin agreement made it a model of how such things should be done and consequently a cornerstone of UNCTAD's ambitious Integrated Programme. For more than 20 years there was little hint that all these strengths could be transformed into weaknesses.

Naturally, there were problems. The inherent instability of the tin market asserted itself repeatedly. Export controls were imposed in 1958, 1968, 1973, 1975 and 1982. For much of the period after the founding of the ITA, however, their imposition was the result not of the commercial balance in the market but of the GSA's buffer stock.

\section{The United States Stockpile}

Although the United States was closely involved with the agreements, it managed the GSA buffer stock without reference to ITA operations. By the time the GSA finally stopped buying tin in 1955 it had accumulated vastly more than had been envisaged. The very existence of what tin traders sardonically called the world's biggest tin mine was enough to distort the market.

But the cessation of GSA buying was in fact the ITA's baptism by fire. The ensuing price collapse forced the first imposition of export controls in 1958. The cumulative disposals that followed were the proximate cause of the imposition of ITC export controls on a number of subsequent occasions.

In the 1970 s, the timing of GSA sales could hardly have been worse. When inflation was rampant tin prices soared, along with other raw material prices. A depreciating pound supported London prices. Between 1974 and 1981, when GSA sales were resumed, the London price more or less doubled from an annual average of $£ 3,494$ a tonne to $£ 7,085$. The Kuala Lumpur price rose from $M \$ 18.8$ a kilogramme to $M \$ 32.34$. If ever there was a time when the GSA could have acted responsibly in the market it was then.
For most of the time the price was near or even above the ceiling of the range in which the buffer stock manager was allowed to intervene. Under ITA rules the manager was obliged to sell tin from his stock to try to keep the price within the agreed range. By 1977 the strain had become too great and stocks were exhausted. Only the GSA could stop prices going up further - which they did - with the consequence that tin production was stimulated. The period 1978 to 1982 saw unrelenting overproduction of tin as ever higher prices depressed demand. This combination of very high prices, low demand, and rising private stocks occurred while the United States was a member of the ITA but while the GSA was absent from the market. They were fertile conditions for disaster.

\section{The Collapse}

The sixth ITA suffered a difficult birth. As the ratification deadline of 30 June 1982 approached negotiations almost broke down. The United States refused to join, a concrete expression of the first Reagan administration's hostility to commodity agreements. Bolivia, afraid that export controls could inhibit its earnings of desperately needed hard currency, also refused to join. Malaysia was both pushing for a higher intervention price and trying to start a cartel of producers without consumers in the belief that direct dealing with consu mers bypassing the LME would keep prices higher. Everything was overshadowed by the LME manipulation and by the parlous financial condition of the buffer stock, which was nevertheless obliged to buy some 50,000 tonnes of tin unloaded by the failed market operators. This tin formed the basis of the Sixth ITA buffer stock.

Attempts by the producers to raise the buffer stock intervention range were successfully resisted by consumers who argued that in the current oversupplied market tin was too expensive, even though prices had fallen to their lowest for five years in the wake of the LME fiasco. In a fateful move it was also agreed to allow the buffer stock manager to borrow commercially against the security of his stocks. Eventually a cliffhanging meeting in Geneva under the auspices of UNCTAD agreed to bring the Sixth ITA into operation without the required number of votes.

It was not an auspicious start. Within days the ITC agreed to impose a 36 per cent cut in tin exports. Malaysia, Indonesia and Thailand announced that they would form an Association of Tin Producing Countries, although stressing that the ATPC was not meant to be a 'tinpec'. There was dissension between the majority among the EEC consumers and Britain and Germany who were suspicious of Malaysia's role in the LME manipulation and wanted guarantees that the ITC would not abuse its market position. 
The Sixth IT A might nevertheless have worked had it not been for three crucial factors: very low world demand for tin, a rapid increase in production by countries outside the ITA coupled with smuggling from ITC producers, and adverse currency movements.

\section{Low Demand}

In 1982 and 1983 consumption of around 154,000 tonnes was the lowest since 1959. By 1985 it had struggled back to the 1980 level of 175,000 tonnes. In 1984 and 1985 several years of draconian export controls - quotas were increased to 39.5 per cent - combined with stronger developed country economic growth to cause modest supply deficits. But it was too late. By that time huge stocks had accumulated at minehead, in LME warehouses, and above all with the ITC. In May 1985 it was reported ${ }^{3}$ that over the previous three years the buffer stock had bought 60,000 tonnes - more than a third of annual consumption - which at the then record prices was

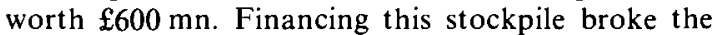
buffer stock.

\section{Production Outside the ITC}

Nor was the reluctance of ITC members effectively to curtail output the buffer stock manager's only problem. The high prices which the agreement had been so successful in engineering during the 1970s had stimulated production in countries outside the agreement, chiefly Brazil and China. In 1981 the ITC nominally still had 71 per cent of world tin production under its sway. Within only four years the percentage had been eroded to 57 .

Tin smuggling is by definition hard to assess accurately, although it has gone on for many years. Private information to the writer suggests, however, that it was running at an annual rate of some 12,000 tonnes in the mid-1980s and may even have reached 20,000 tonnes, despite special efforts by the ITC to curb it.

Most of the smuggling is from Thailand where a sizeable part of tin mining is controlled by what amounts to organised crime beyond government control. The tin is sent to Singapore where it is smelted and sold as Malaysian material. In normal times this smuggling might not have mattered, and would de facto have been just another part of the market. But in 1985 it was a problem the buffer stock manager could do without.

\section{Currency Swings}

What in the end made financing the stockpile and soaking up all the extra tin in the world impossible was

\footnotetext{
${ }_{3}^{3}$ Financial Times, 17 May 1985.
}

the appreciation of sterling against the Malaysian ringgit.

In 1972, at the instigation of its largest producer, the ITC decided to denominate the buffer stock price range in Malaysian ringgits. The floor price to be defended became the Kuala Lumpur tin price, even though the bulk of world tin trading was done through the LME. But buffer stock operations would still be conducted in sterling. Currency exposure was therefore an integral part of the ITC. Not only was the buffer stock exposed to arbitrage (buying and selling to take advantage of price differences between centres) between London and Kuala Lumpur but part of the arbitrage was caused by currency movements outside the manager's control.

The core of the problem was that the Malaysian dollar is closely linked to the US dollar. So when the US dollar was strong and appreciating the Malaysian currency went up with it. A strong local currency generally keeps down local commodity prices expressed in other currencies (in this case, sterling). This tended to put pressure on the Kuala Lumpur floor price. But the obverse of the strong dollar was a weak pound sterling and high and rising nominal prices on the LME. Consequently, as we have seen, London tin prices reached record levels in late 1984 and early 1985 despite unfavourable supply and demand and stock balances. Since the buffer stock had bought its tin in 1982 at around $£ 7,000$ a tonne, prices of $£ 9,000$ or more allowed the buffer stock manager to show handsome paper profits. He borrowed against these illusory gains to finance support for the Kuala Lumpur floor price, which he was obliged by the IT A to do.

Then, abruptly, in early 1985 the whole process went into reverse. Sterling rose from almost parity with the dollar to $\$ 1.40$. Between February and October the LME tin price collapsed by virtually $£ 2,000$ a tonne to $£ 8,140$ on the morning of 24 October. Pieter de Koning tried to stem the tide by persuading the ITC in March to allow him to trade below the Kuala Lumpur floor price. His logic was that the cost of his London collateral being devalued was much greater than the incremental cost of supporting the Malaysian price.

Weakening prices tempted speculators to sell tin short - to sell tin they did not own in the hope that by the time the contracts fell due the price would have fallen below the contract price. The buffer stock executed a devastating squeeze on the market at the end of June by insisting that traders who had agreed three months earlier to sell to it should provide metal, not cash. But the only source of so much spot tin was the ITC itself. The old animosity between the LME and the ITC flared up again as the LME limited the backwardation 
which developed. The public row which ensued between de Koning and the LME authorities was reminiscent of 1982 .

Not that de Koning had lacked ingenuity. As tne later audit of the ITC by the accountants Peat Marwick Mitchell showed, the buffer stock had entered into a complex web of deals with metal brokers, mainly on the LME. In essence these arrangements enabled the buffer stock to stretch its already thin finances, with the incidental advantage of disguising how thin they were, and take on more tin that would otherwise have been possible. One device was to borrow money from brokers to buy more tin, often from the same brokers who lent the money. Another was to 'borrow' tin in such a way that the buffers stock paid only interest and a premium rather than the full cost of outright purchase. Several LME brokers were only too happy to do business with the ITC. Metal markets generally were depressed, and at the very high prices prevailing in mid-1985 the buffer stock was just about the only buyer. After all, was it not backed by 22 sovereign states?

But however ingenious his defence of the price, the buffer stock manager's position was fatally undermined by the relentless fall in London prices which prompted margin calls from his brokers and calls for more collateral from his bankers. As early as March the ITC support operation had lost $£ 20 \mathrm{mn}$. In September the ATPC pledged $£ 60 \mathrm{mn}$ to the buffer stock. Most of the money never arrived, although it might have sustained the operation for another six months. Squeezed in this pincer the ITC buffer stock simply ran out of money on the morning of 24 October.

\section{The Default}

What happened thereafter has been well chronicled in the press. ${ }^{4}$ After months of frustrating prevarications during which tin trading virtually stopped because nobody could be sure of the price, the ITC failed to agree on how to refinance its debts of $£ 900 \mathrm{mn}$. Neither the diplomacy of the British government - the only developed country which said it would pay its share of the debts - nor the ingenuity of the ITC's creditors led by Standard Chartered Bank at the suggestion of the Bank of England could create a consensus at the ITC. In December the ITC went into a supposedly open-ended session to bring about a solution. But after its failure to agree the deadlock was broken on 12 March by the LME enforcing a settlement between its members of all outstanding tin contracts, including those with the ITC. At the time of writing, tin is trading at around half its suspension price of $£ 8,140$ a tonne.

\footnotetext{
${ }^{4}$ See particularly The Times and Financial Times between October 1985 and April 1986

${ }_{5}$ The Times 2 December 1985 and Financial Times 5 December 1985.
}

The failure of 22 countries, several of them rich nations prone to lecturing the Third World on financial probity, was all the more extraordinary given the desperation of creditor banks and brokers to settle. The plan which eventually emerged by January 1986 was that a company - first called Newco and later Tinco - would be set up to take on all the ITC's 80,000 tonnes of tin. Tinco would be capitalised with $£ 200 \mathrm{mn}$ subscribed in equal measure by ITC consumer and producer members, $£ 70 \mathrm{mn}$ from the banks and brokers, and $£ 50 \mathrm{mn}$ of loan capital from the British government. In return the ITC would be freed of all obligations and Tinco would oversee an orderly disposal of the tin. By the end of the haggling in early March the creditors had agreed to increase their share to at least $£ 100 \mathrm{mn}$, with a corresponding reduction in the ITC's share of Tinco's capitalisation. Even that 'burden sharing' was not enough.

\section{The ITC's Debts}

Two aspects of the default - probably the biggest in commercial history - deserve attention: the details of what the ITC owed, and why the default occurred.

On 24 October the ITC held 52,540 tonnes of physical tin. If all pending transactions had been completed, the buffer stock's net holding would have been 49,590 tonnes (worth $£ 400 \mathrm{mn}$ at the suspension price). The frightening aspect of the figures, however, was that the buffer stock would have incurred by the end of January debts of $£ 900 \mathrm{mn}$, of which $£ 281 \mathrm{mn}$ would have been to 14 creditor banks and the rest to metal traders. With the value of its collateral falling continuously, there was no way these debts could have been met, except by the members subscribing more funds to the council. The LME settlement of March at a set price of $£ 6,250$ a tonne left the ITC owing metal brokers $£ 180 \mathrm{mn}$.

\section{The Debtors' Motives}

The argument put forward unofficially by several members, notably Germany, France and the Netherlands, was that the council enjoyed diplomatic immunity: it could not be prosecuted for its debts. Indeed, one remarkable discovery in the I'TA was that it contained no provision for bankruptcy, an optimistic piece of drafting for which UNCTAD must assume some responsibility. Legal opinion differs on the degree of immunity the ITC enjoys and certainly the British government has been advised that the immunity is not watertight. As brokers bring actions against the ITC and its members this will be tested.

But whether or not the ITC enjoys diplomatic immunity begs the question of why members chose to hide behind it. The more charitable explanation is that the customary working method of the ITC made 
agreement difficult to reach. The usual procedure was to discuss business until a consensus emerged. It was a method plainly ill-suited to a crisis, especially one which appears to have caught many members unawares. The argument made by some European countries that this was a British crisis and that the main interest of the British government was to protect the LME was probably little more than an excuse.

Whatever the ITC's mechanisms, and whatever members knew about what was going on, there was considerable reluctance from the outset to meet the debts. Significantly, the ITC did not say immediately 'We will honour all obligations freely entered into' and then work out how to do it. To the author, who covered the crisis as a reporter from beginning to end, there was from a very early stage the smell of default in the air. Yet one suspended judgement simply because the very idea of so big a default by such debtors was almost unthinkable.

One factor which made it so, apart from straightforward commercial considerations, was that only three years earlier these same countries had solemnly brought the Sixth ITA into being. France and the Netherlands, had even made special contributions to smooth the path. What had changed?

One major change between 1982 and 1985 was a hardening of government attitudes towards community pacts as all raw material prices fell, led by OPEC, and the decline into ineffectiveness if not disuse of most commodity agreements (coffee perhaps being the exception). The other important change was specific to tin. Tin stocks mounted and the market was continuously oversupplied yet prices rose. An agreement unable to maintain sensible prices could not properly serve the interests of producer or consumer.

The impression of a lapse of attention if not downright negligence on the part of ITC members is reinforced by their reactions to the audit. A swift reaction was to accuse the buffer stock manager of trading beyond his remit. But it was the responsibility of the members to peruse this vital part of the agreement. In its reply to the Select Committee on 'Trade and Industry, which was highly critical of the British government's role in the crisis, the government claimed that its delegates reported fully the situation in the ITC and that warnings of possible financial problems were transmitted to the City via the Bank of England. ${ }^{6}$ It is understood, however, that the delegate's reports were

\footnotetext{
${ }^{6}$ House of Commons Paper 457. Fifth Special Report from the Trade and Industry Committee, session 1985-86, The Tin Crisis: Observations by the Government on the Second Report of the Trade and Industry Committee in Session 1985-86. ordered to be printed 11 July 1986
}

so bland as to be unlikely to land on a minister's desk. That successive British ministers were fully appraised of an impending crisis in the ITC is very doubtful. It is likely that the same was true in other countries, particularly the consumers.

The Seventh ITA would have been due in happier times to come into force next year. Nobody is rushing to negotiate a new agreement, especially given the complications of court proceedings by creditors. To all intents and purposes, however, the 22 members have turned their backs on the ITC and on the longest running commodity agreement.

\section{Conclusions}

The immediate cause of the ITC's default was that too many of its members did not believe it was worth financing. The decision was taken in a climate very different from that in which the ITC was born. Commodity prices are structurally very low, as is faith in the effectiveness of agreements. Some powerful governments - notably Britain and the United States - are more committed to free markets than were their predecessors. Life has also been complicated for commodity agreements by the revolution in financial markets: colossal flows of capital around the world, aided by technological advances and the lowering of barriers to capital transfers, have created massive speculative forces which nation states, let alone a modestly funded commodity agreement, cannot resist.

But this does not explain what happened specifically to the ITA. There are three main reasons for the collapse, and each has its lesson.

First, the root of members' disenchantment with the ITA was its meretricious success in keeping tin prices high. In 1984 copper and lead prices measured in US cents per pound were only 60 per cent higher than the corresponding averages for 1956. Zinc and aluminium were three times higher. But tin was six times higher [Roskill 1985:1]. Why the consumer members of the ITC agreed to support such unrealistic prices is a very important question for future commodity agreements. The lesson is that to succeed a commodity agreement with economic (i.e. pricing) clauses must pitch its intervention range reasonably in line with the market. Surviving and meeting members' needs are better served by aiming for price stability and a predictable income than by forcing prices up.

Second, when the ITC started life it was a cartel with the unusual feature of consumer members. But high prices inevitably attracted other producers into the market while also promoting consumers to ask whether the agreement was in their interest. A corollary is that as more developing countries exploit 
their natural resources, commodity agreements of all kinds will require so many members to be effective as to be unwieldy. The coffee agreement, for example, has difficulty policing all its members. The lesson is that few agreements are likely to be comprehensive enough to last long.

And third, it may be that as developing countries diversify their economies, the need for commodity agreements will diminish. When Malaysia helped set up the ITC, tin accounted for almost a quarter of its exports by value. By 1985 tin contributed only three per cent. Commodities may still overall be a significant part of Malaysia's foreign trade, but can countries be expected to belong to a clutch of different agreements? Malaysia has not joined OPEC for instance. The lesson is that here lies a formidable obstacle to the ambitions of the Integrated Fund.

In any case, such ambitions have been severely dented by the tin fiasco. The tin price has collapsed to its lowest real level since before the war, and the ITC's default has brought misery to mining communities around the world. Mines have closed, and weaker economies such as Bolivia are endangered. Future agreements will have to be very carefully drafted indeed if fears of a similar default are to be allayed. A cloud hangs over many intergovernmental organisations, and not the least consequence of the default is even greater caution by banks in lending. The ITC has set back the cause of commodity agreements. Yet the doubt remains that leaving commodity pricing to the likes of the LME is no alternative.

\section{Sources and References}

This article has been compiled mainly from my own notebooks and articles written for The Times. Some of the information, in the nature of newspaper reporting, was supplied privately and in confidence. For my limited understanding of the tin market I owe much to David Williamson, the tin expert at Shearson Lehman Brothers in London.

For earlier statistics I used:

Crowson, P., 1984, Minerals Handbook 1984-5, Macmillan London

Roskill Information Services Ltd, 1985, The Economics of Tin 1985, fourth ed., Roskill Information Services Ltd, London

Shearson Lehman Brothers, 1985, Annual Review of the World Tin Industry 1985, London 